\title{
The influence of epidural anesthesia on the electrical activity of heart atria
}

\author{
Pawel Twardowski ${ }^{1}$, Radoslaw Owczuk ${ }^{1}$, Magdalena A. Wujtewicz ${ }^{1}$, Jacek Wojciechowski², \\ Tomasz Marjanski ${ }^{3}$, Andrzej Marciniak ${ }^{1}$, Maria Wujtewicz ${ }^{1}$ \\ ${ }^{1}$ Department of Anaesthesiology and Intensive Therapy, Medical University of Gdańsk, Gdańsk, Poland \\ 2Department of Cardiac and Vascular Surgery, Medical University of Gdańsk, Gdańsk, Poland \\ ${ }^{3}$ Department of Thoracic Surgery, Medical University of Gdańsk, Gdańsk, Poland
}

Kardiochirurgia i Torakochirurgia Polska 2014; 11 (2): 156-161

\begin{abstract}
Introduction: High thoracic epidural anesthesia (TEA) causes blockade of sympathetic fibers involved in innervation of the heart (segments T1-T4), which results in changes of cardiac electrophysiology. The anti-arrhythmic effects of TEA on supraventricular arrhythmias, mainly atrial fibrillation, are controversial.

The aim of the study was to assess the influence of epidural anesthesia on the electrical function of heart atria, including proven markers of increased risk of perioperative atrial fibrillation, such as $\mathrm{P}$ wave dispersion and $\mathrm{P}$ wave maximum duration.

Material and methods: The study involved 50 male patients, without a history of previous heart diseases, scheduled for elective surgical procedures. Patients received thoracic epidural anesthesia (group T, $n=25$ ) or lumbar epidural anesthesia (group L, $n=25$ ). The measurements were obtained from a continuous recording of ECG before epidural anesthesia and after the detection of blockade ( $\mathrm{T} 1$ or $\mathrm{T} 8$ segment sensory block in groups $\mathrm{T}$ and $\mathrm{L}$, respectively).

Results: The statistical analysis of electrocardiographic parameters, including the maximum, minimum and mean $P$ wave duration; $P$ wave dispersion; the maximum, minimum and mean PR interval duration; and PR interval dispersion, did not show any inter- or intragroup differences at selected time points.

Conclusions: Regardless of its location, epidural anesthesia and sympathetic blockade associated with this procedure do not significantly affect the electrical functions of the cardiac atria reflected in superficial ECG, including the electrocardiographic parameters that are considered to be markers of increased risk of perioperative atrial fibrillation, such as $P$ wave dispersion and its maximum duration.
\end{abstract}

Key words: epidural anesthesia, sympathetic denervation, cardiac electrophysiology, electrocardiography.

\section{Streszczenie}

Wstęp: Znieczulenie zewnątrzoponowe w odcinku piersiowym powoduje blokadę włókien współczulnych odpowiedzialnych za unerwienie serca (poziom Th1-Th4), co skutkuje zmianami jego elektrofizjologii. Antyarytmiczny efekt znieczulenia zewnątrzoponowego w odniesieniu do nadkomorowych zaburzeń rytmu serca, głównie migotania przedsionków, jest niepewny.

Cel pracy: Ocena wpływu znieczulenia zewnątrzoponowego na funkcję elektryczną przedsionków serca, w tym na udowodnione markery ryzyka wystąpienia okołooperacyjnego migotania przedsionków, takie jak dyspersja załamka P oraz jego maksymalny czas trwania.

Materiał i metody: W badaniu wzięło udział 50 nieobciążonych chorobami układu sercowo-naczyniowego mężczyzn, poddanych zabiegom chirurgicznym w trybie elektywnym. Wykonywano znieczulenie zewnątrzoponowe $w$ odcinku piersiowym (grupa T, $n=25$ ) lub lędźwiowym (grupa L, $n=25$ ). Pomiarów dokonywano za pomocą zestawu do ciągłego zapisu krzywej EKG w dwóch punktach czasowych - przed wykonaniem blokady oraz w momencie osiągnięcia przez blokadę zakładanego poziomu (blokada czuciowa na poziomie Th1 - grupa T lub Th8 - grupa L).

Wyniki: Analiza statystyczna badanych parametrów elektrokardiograficznych: maksymalnego, minimalnego oraz średniego czasu trwania załamka P; dyspersji załamka P; maksymalnego, minimalnego oraz średniego czasu trwania odstępu PR; dyspersji odstępu PR - nie wykazała występowania różnic wewnątrz oraz pomiędzy badanymi grupami w zdefiniowanych punktach czasowych.

Wnioski: Niezależnie od jego lokalizacji znieczulenie zewnątrzoponowe i związana z nim blokada współczulna nie wpływają istotnie na funkcję elektryczną przedsionków serca, odzwierciedlaną w powierzchniowym zapisie EKG, w tym na parametry elektrokardiograficzne uznawane za markery zwiększonego ryzyka okołooperacyjnego migotania przedsionków, takie jak dyspersja załamka $\mathrm{P} \mathrm{i} \mathrm{jego} \mathrm{maksymalny} \mathrm{czas} \mathrm{trwania.}$

Słowa kluczowe: znieczulenie zewnątrzoponowe, denerwacja współczulna, elektrofizjologia serca.

Address for correspondence: Pawel Twardowski, Department of Anaesthesiology and Intensive Therapy, Medical University of Gdańsk, 17 Smoluchowskiego St., 80-952 Gdańsk, Poland, tel. +48 5834932 70, fax +48 58349 32 90, e-mail: p.twardowski@gumed.edu.pl 


\section{Introduction}

Due to its analgesic properties, epidural anesthesia is still a frequently used component of anesthesia during major procedures within the abdominal cavity or in thoracic surgery. As local anesthetics (LA) used in epidural anesthesia have a high affinity to the sympathetic fibers, this type of anesthesia is associated with sympathetic blockade. High thoracic epidural anesthesia (TEA) involving the first four thoracic segments will result in a significantly reduced influence of the sympathetic system on the heart. TEA-induced predominance of the parasympathetic system may lead to significant changes in the functioning of the cardiac conduction system [1]. A disproportion between two components of the autonomic nervous system (ANS) is one of the main reasons for supraventricular cardiac arrhythmias in patients subjected to cardiac and thoracic surgery. It is mainly a result of surgical damage to the parasympathetic fibers and activation of the sympathetic system occurring during the surgery [2]. It would seem that TEA-associated sympathetic blockade may reduce the risk of supraventricular cardiac arrhythmias. However, it is not possible to draw unanimous conclusions based on analysis of the comprehensive literature in this field [3].

The risk of arrhythmogenicity can be estimated based on some elements of superficial electrocardiographic recordings. The risk of occurrence of supraventricular tachyarrhythmias, i.e. atrial fibrillation (AF), rises with a prolonged $P$ wave maximum duration $\left(P_{\max }\right)$, as well as with the increased $P$ wave dispersion (PWD) value [4]. The autonomic system affects these parameters mainly as a result of changes in the rate of intra-atrial conduction, while in the case of sympathetic system activation, conduction heterogeneity is increased together with the $P_{\max }$ and PWD value, and as a result of atrial enlargement, which is secondary to a long-lasting increased sympathetic activity resulting also in the increase of PWD and atrial depolarization [5].

\section{Aim of the study}

So far, there have been no publications describing changes in the electrophysiological parameters of the cardiac atria due to sympathetic blockade accompanying epidural anesthesia. This study was performed to determine whether epidural anesthesia and the accompanying sympathetic blockade affect the electrical functions of the cardiac atria reflected by superficial ECG, including wellknown risk markers for perioperative atrial fibrillation, such as $P$ wave dispersion and its maximum duration. We also wanted to find out whether the potential effects of epidural anesthesia on atrial electrophysiology depend on the blockade location.

\section{Material and methods}

The study was approved by the Independent Bioethics Committee for Research Studies at the Medical University of Gdansk. Patients considered eligible for the study were extensively informed of the study aim and methods, and provided written consent for their participation in the study.

It was a prospective parallel study and was conducted in 50 patients subjected to elective surgical procedures. Eligible subjects included male patients aged from 18 to 65 years, who matched the American Society of Anesthesiologists (ASA) definitions for physical status I or II. Patients were excluded from the study if they were receiving anti-arrhythmic agents belonging to group 1-3 according to the Vaughan-Williams classification, had ischemic heart disease, a history of cardiac arrhythmia, or in cases of presence of abnormalities in pre-operative ECG.

Patients were divided into two equal groups: a group that received thoracic epidural anesthesia (T group, $n=25$ ) and a group that received lumbar epidural anesthesia (L group, $n=25$ ). The patients' classification into groups depended on the body area that was operated on: patients subjected to procedures in the chest received thoracic epidural anesthesia, whereas patients who had surgery in the abdominal cavity received epidural anesthesia in the lumbar region. To avoid any potential effects of drugs used for premedication on the tested parameters, they were not administered.

ECG waveforms were continuously recorded using a 12-lead Holter system, Mortara $\mathrm{H} 12+$, with the sampling frequency of $1000 \mathrm{~s}^{-1}$, by Mortara Instruments (Milwaukee, WI, USA). Epidural anesthesia was performed using a Tuohy $18 \mathrm{G}$ needle, and a loss of resistance technique with sterile $0.9 \% \mathrm{NaCl}$ solution. When the epidural space was identified, a catheter was placed inside and a test dose of $3 \mathrm{~mL}$ of $2 \%$ lidocaine was administered. After waiting for at least five minutes to ensure appropriate catheter location, a $0.5 \%$ bupivacaine solution (bupivacaine hydrochloride $0.5 \%$; Polfa Warsaw; Poland) was administered at a volume appropriate to achieve an adequate level of anesthesia, depending on the patient's age and height, as well as a scheduled surgical procedure. From that point, the blockade extent was assessed every five minutes using an alcohol-soaked swab to evaluate the loss of ability to sense cold. During the study, the arterial blood pressure was measured every five minutes. The heart rate and arterial blood hemoglobin saturation with oxygen were measured continuously and their values were recorded at five-minute intervals. Until the end of the study, the patients did not receive any fluids except for a basic, slow infusion with a $0.9 \% \mathrm{NaCl}$ solution. The study was completed when the sensory blockade reached the T1 dermatome in the T group or T8 in the L group. After the completion of the study, general anesthesia and the surgical procedure continued.

The registered electrocardiographic parameters were assessed at two time points: "TO", prior to epidural anesthesia; and "T1", when the blockade reached the T1 level in the group of patients with thoracic anesthesia, or T8 for lumbar anesthesia. The following ECG waveform parameters were assessed:

- the maximum, minimum and mean $\mathrm{P}$ wave duration in 12 leads, 
- $P$ wave dispersion (the difference between the maximum and minimum $P$ wave duration in 12-lead ECG),

- the maximum, minimum and mean duration of PR interval in 12 leads,

- the PR interval dispersion (the difference between the maximum and minimum duration of PR interval in 12-lead ECG).

The parameters' values were read after a 4-fold magnification of the waveform on a monitor with $1920 \times 1080$ resolution. The achieved values are means of three subsequent ECG evolutions at prespecified time points.

\section{Statistical analysis}

The statistical analysis was prepared using Statistica 9.0 for Windows PL (StatSoft, Tulsa, USA). The minimum number of tested patients was determined to be 24 subjects per group, but in order to avoid potential "losses" during the follow-up, it was increased to 25 per group. Calculations were performed using data provided by Gunduz et al. [6], who determined the mean PWD value in a group of healthy subjects to be $43 \pm 9 \mathrm{~ms}$. A change in the $P$ wave value of $20 \%$ was considered to be significant. The values of $\alpha=0.05$ and $\beta=0.90$ were assumed. A normal distribution of continuous variables was verified with the Shapiro-Wilk $W$ test. Inter-group comparisons were performed using Student's $t$-test for unassociated variables in the case of data with a normal distribution or the Mann-Whitney $U$ test for data without such a distribution. Changes in parameter values in time (intra-group comparisons) and differences between groups for the same time points (inter-group comparisons) were analyzed using Fisher's ANOVA variance test, with an assumption to use the post-hoc Tukey's HSD (honest significant difference) test, if applicable.

The value of $p<0.05$ was considered to be significant.

\section{Results}

Table I presents characteristics of the studied patients. No statistically significant differences between the tested groups with regard to age, height, body weight or BMI index were observed. Table II presents the values of mean ar- terial pressure, heart rate and tested electrocardiographic parameters. A statistically significant decrease of the mean arterial pressure after epidural anesthesia was observed in both groups $(p=0.0005)$. In addition, a statistically significant decrease in the heart rate after epidural anesthesia was observed in the T group ( $p=0.0002)$, but there were no statistically significant differences for this parameter in the $L$ group. A statistical analysis of changes in the tested electrocardiographic parameters did not demonstrate intra- or inter-group differences between the tested groups at prespecified time points.

\section{Discussion}

Our study is an attempt to assess the effects of epidural anesthesia on the electrical activity of the cardiac atria. In clinical practice, the $P$ wave maximum duration and its dispersion are considered to be parameters of the highest value in the assessment of the electrical activity of the atria [4]. In the groups we studied, there were no statistically significant effects of epidural anesthesia on the minimum, maximum, or mean $\mathrm{P}$ wave duration. There were no changes, regardless of whether there was lumbar epidural anesthesia, where sympathetic blockade does not include the fibers innervating the heart, or whether there was thoracic epidural anesthesia involving those fibers.

These observations are to some extent contradictory to literature data demonstrating the effects of sympathetic stimulation and blockade on the parameters mentioned above. These studies were based on pharmacological tests and in almost all cases the conclusion was that the $P$ wave duration changes significantly depending on induced changes in the sympathetic system tone. In their study, Cheema et al. concluded that a propranolol-induced sympathetic blockade resulted in prolonged $P$ wave duration. On the other hand, blockade of both components of the autonomic system, induced by concomitant administration of propranolol and atropine, reduced the duration of atrial depolarization [5]. It might be expected that direct, short-lasting blockade of the sympathetic fibers innervating the heart should result in the prolonged duration

Tab. I. Patients' characteristics

\begin{tabular}{|c|c|c|c|}
\hline Factors & Group T & Group L & $p$ value \\
\hline Age (years) & $53.9 \pm 6.2(51.3-56.6)$ & $51.6 \pm 10.5(47.1-56.2)$ & 0.36 \\
\hline Body mass (kg) & $70.5 \pm 9.5(66.4-74.5)$ & $74.4 \pm 11.3(66.6-79.0)$ & 0.35 \\
\hline Height (cm) & $173,8 \pm 5.9(171.3-176.2)$ & $175.4 \pm 6.3(172.8-178.0)$ & 0.20 \\
\hline Body mass index $\left(\mathrm{kg} \mathrm{m}^{-2}\right)$ & $23.3 \pm 2.8(22.1-24.5)$ & $24.2 \pm 3.4(22.8-25.6)$ & 0.34 \\
\hline \multirow[t]{4}{*}{ Level of puncture (n) } & Th5-Th6 (1) & & \\
\hline & Th6-Th7 (20) & L1-L2 (20) & \\
\hline & Th7-Th8 (3) & L2-L3 (5) & \\
\hline & Th8-Th9 (1) & & \\
\hline Volume of bupivacaine administered $(\mathrm{mL})$ & $7-12$ & $12-20$ & 0.000001 \\
\hline
\end{tabular}

Group T - patients scheduled for thoracic epidural anesthesia. Group L - patients scheduled for lumbar epidural anesthesia. 
of atrial depolarization and of the electrical impulse conduction in the atria. In the studies involving subjects with cardiac diseases, different observations were made: shortlasting sympathetic blockade induced by $\beta$-blockers, e.g. metoprolol, in patients with acute coronary syndromes resulted in decreased $P_{\max }$ and reduced PWD values [7]; similar effects were observed in patients with mitral stenosis subjected to long-term $\beta$ receptor blockade [8]. It can be assumed that the effects of adrenergic blockade on the $P_{\text {max }}$ different from the ones we observed were primarily a result of a structural heart disease in patients involved in the studies mentioned above.

The effects on the analyzed parameters are also a result of the indirect TEA influence. It is known that this type of anesthesia significantly affects the coronary flow (via vasodilatation), slows down the heart rate, and brings about the improvement of the coronary flow during diastole [9]. This latter effect was extremely visible in patients in the T group. Based on the analysis of available literature, it can be concluded that reduced blood flow through the coronary arteries is associated with $P_{\max }$ prolongation $[10,11]$, whereas the improvement of blood flow through the right coronary artery as a result of its percutaneous plasty shortens the $P$ wave duration [9]. The results of the studies by other authors presented above may explain, to a large extent, the fact that we did not observe any significant effects of TEA on the minimum, maximum and mean $P$ wave duration. On the one hand, epidural anesthesia causes blockade of the sympathetic fibers innervating the heart, which - in subjects not suffering from a heart disease - should result in the prolongation of the studied duration values. On the other hand, potentially significant effects on the coronary flow have an opposite impact, resulting in the decrease of these values.

$P$ wave dispersion, a derivative of $P$ wave duration values, was another assessed parameter. The usefulness of this parameter to assess the risk of supraventricular cardiac arrhythmias has been confirmed in a great number of studies including a temporal coincidence between the $P$ wave dispersion value and episodes of atrial fibrillation in patients subjected to cardiac surgery. Chandy et al. studied the predictive value of $P$ wave dispersion in patients subjected to coronary bypass surgery. They concluded that an increase in the PWD value in the postoperative period in relation to the value prior to the procedure was closely related to the risk of an atrial fibrillation episode [12].

As in the case of the minimum, maximum and mean $P$ wave duration, the majority of authors of published studies observed significant effects of changes in the tone of the sympathetic components on PWD in patients with circulatory system risk factors, whereas there are no reports describing the effects of adrenergic blockade on PWD in subjects without a heart condition. In studies involving patients with cardiac disorders, it was concluded that $\beta$-blockers cause a decrease in the PWD values. This situation was observed following metoprolol administration to patients with acute coronary syndrome [7] and with congestive heart failure [13], as well as after chronic use of
Tab. II. Changes in the selected hemodynamic and electrocardiographic parameters following epidural anaesthesia

\begin{tabular}{|c|c|c|c|}
\hline Factors & Before & After & $p$ value \\
\hline \multicolumn{4}{|c|}{ Mean arterial pressure } \\
\hline Group T & $\begin{array}{l}100.4 \pm 12.6 \\
(94.9-105.9)\end{array}$ & $\begin{array}{l}85.9 \pm 12.4 \\
(80.6-91.2)\end{array}$ & \multirow{2}{*}{0.0005} \\
\hline Group L & $\begin{array}{l}102.7 \pm 9.7 \\
(98.1-107.4)\end{array}$ & $\begin{array}{l}87.2 \pm 13.8 \\
(80.6-93.9)\end{array}$ & \\
\hline
\end{tabular}

\begin{tabular}{llll}
\hline Heart rate & & & \\
\hline \multirow{2}{*}{ Group T } & $79.9 \pm 10.9$ & $68.2 \pm 11.1$ & \\
& $(75.4-84.4)$ & $(63.6-72.7)$ & 0.0002 \\
\cline { 1 - 3 } Group L & $82.6 \pm 16.0$ & $83.2 \pm 14.5$ & \\
\hline
\end{tabular}

\begin{tabular}{cccc}
\hline$P_{\text {min }}$ & & & \\
\hline \multirow{2}{*}{ Group T } & $84.4 \pm 7.1$ & $87.2 \pm 11.1$ & \\
\cline { 1 - 2 } Group L & $(81.5-87.3)$ & $(82.6-91.8)$ & \multirow{2}{*}{0.753} \\
& $(72.4 \pm 8.9$ & $84.3 \pm 7.3$ & \\
\hline
\end{tabular}

\begin{tabular}{cccc}
\hline$P_{\max }$ & & & \\
\cline { 1 - 2 } Group T & $\begin{array}{c}115.4 \pm 7.2 \\
(112.4-118.3)\end{array}$ & $\begin{array}{c}115.2 \pm 9.8 \\
(111.2-119.2)\end{array}$ & \\
\cline { 1 - 3 } Group L & $\begin{array}{c}122.0 \pm 9.9 \\
(117.9-126.1)\end{array}$ & $\begin{array}{c}121.4 \pm 5.7 \\
(119.1-123.8)\end{array}$ &
\end{tabular}

\begin{tabular}{cccc}
\hline$P_{\text {mean }}$ & & & \\
\hline \multirow{2}{*}{ Group T } & $101.5 \pm 6.3$ & $103.3 \pm 7.7$ & \\
\cline { 1 - 2 } Group L & $(98.9-104.1)$ & $(100.1-106.6)$ & \multirow{2}{*}{0.486} \\
& $(103.9 \pm 6.5$ & $104.6 \pm 6.4$ & \\
\hline
\end{tabular}

PWD

\begin{tabular}{|c|c|c|c|}
\hline Group T & $\begin{array}{l}30.9 \pm 7.6 \\
27.8-34.1)\end{array}$ & $\begin{array}{l}28.0 \pm 13.1 \\
(226-33.4)\end{array}$ & \multirow[b]{2}{*}{0.912} \\
\hline Group L & $\begin{array}{l}37.9 \pm 10.2 \\
(34.5-41.2)\end{array}$ & $\begin{array}{c}35.3 \pm 6.1 \\
(30.8-39.9)\end{array}$ & \\
\hline
\end{tabular}

\begin{tabular}{|c|c|c|c|}
\hline \multicolumn{4}{|c|}{$(30.8-39.9)$} \\
\hline \multicolumn{4}{|l|}{$P R_{\min }$} \\
\hline Group T & $\begin{array}{c}143.6 \pm 13.7 \\
(137.9-149.2)\end{array}$ & $\begin{array}{c}146.2 \pm 17.5 \\
(139.0-153.4)\end{array}$ & \multirow{2}{*}{0.175} \\
\hline Group L & $\begin{array}{c}139.0 \pm 15.9 \\
(132.4-145.5)\end{array}$ & $\begin{array}{l}134.0 \pm 30.6 \\
(121.3-146.6)\end{array}$ & \\
\hline \multicolumn{4}{|l|}{$P R_{\max }$} \\
\hline Group T & $\begin{array}{c}178.3 \pm 17.6 \\
(171.0-185.6)\end{array}$ & $\begin{array}{c}180.6 \pm 20.1 \\
(172.3-188.9)\end{array}$ & \multirow{2}{*}{0.516} \\
\hline Group L & $\begin{array}{c}178.8 \pm 16.1 \\
(172.1-185.4)\end{array}$ & $\begin{array}{l}178.7 \pm 17.9 \\
(171.3-186.1)\end{array}$ & \\
\hline \multicolumn{4}{|l|}{$\mathrm{PR}_{\text {mean }}$} \\
\hline Group T & $\begin{array}{c}161.0 \pm 15.7 \\
(154.5-167.4)\end{array}$ & $\begin{array}{c}163.6 \pm 18.2 \\
(156.0-171.0)\end{array}$ & \multirow{2}{*}{0.348} \\
\hline Group L & $\begin{array}{c}159.4 \pm 15.4 \\
(153.0-165.7)\end{array}$ & $\begin{array}{c}159.3 \pm 17.2 \\
(152.2-166.4)\end{array}$ & \\
\hline
\end{tabular}

\begin{tabular}{|c|c|c|c|}
\hline \multicolumn{4}{|c|}{ PR dispersion } \\
\hline Group T & $\begin{array}{l}34.7 \pm 11.9 \\
(29.8-39.6)\end{array}$ & $\begin{array}{c}34.4 \pm 8.8 \\
(30.8-38.0)\end{array}$ & \multirow{2}{*}{0.335} \\
\hline Group L & $\begin{array}{l}39.8 \pm 13.3 \\
(34.3-45.3)\end{array}$ & $\begin{array}{l}44.7 \pm 27.7 \\
(33.3-56.2)\end{array}$ & \\
\hline
\end{tabular}

The data are the mean (95\% confidence interval).

Group T - patients scheduled for thoracic epidural anesthesia. Group L - patients scheduled for lumbar epidural anesthesia.

$P_{\text {min }}-P$ wave minimum duration, $P_{\max }-P$ wave maximum duration, $P_{\text {mean }}-$ $P$ wave mean duration, $P W D-P$ wave dispersion, $P R_{\min }-P R$ interval minimum duration, $P R_{\text {max }}-P R$ interval maximum duration, $P R_{\text {mean }}-P R$ interval mean duration, $P R$ dispersion - PR interval dispersion 
$\beta$-blockers in patients with mitral valve stenosis [8]. On the other hand, an increase in the PWD values was observed in patients with exacerbated anxiety [14] and in patients with cardiac syndrome $X$ [15], as these conditions are associated with an increased tone of the sympathetic system. Such changes were not, however, observed in the groups we studied, and we had expected them to appear mainly in the group receiving thoracic anesthesia ( $T$ group).

The lack of effects of thoracic anesthesia on PWD we observed cannot be explained in a similar way to the lack of TEA effects on the minimum, maximum and mean $P$ wave duration. While TEA-induced contrary effects of sympathetic fiber blockade and of the changes in the coronary flow can account for the lack of changes in the $P$ wave duration, TEA-induced sympathetic blockade and a coronary flow increase have the same, reducing effects on the PWD values [9-11]. Additionally, it is more difficult to interpret the results due to the lack of changes in the tested parameters in the L group. In contrast to patients in the T group, those with lumbar epidural anesthesia were expected to show increased compensatory activity of the sympathetic system in the unblocked segments, including the T1-4 segments innervating the heart [16]. Low epidural anesthesia may, therefore, cause an imbalance between the activity of the sympathetic and parasympathetic parts of the ANS, increasing the activity of the former and not affecting the latter significantly. A similar situation can be observed for spinal anesthesia. Significant prolongation of the corrected QT interval (QTc) value was observed after spinal anesthesia reaching the T10 level (the level of sensory blockade), and the authors related this event to compensatory stimulation of the remaining sympathetic fibers in the upper part of the thoracic segment of the spinal cord [17]. With regard to the results of these studies, one might have expected that sympathetic blockade in the lumbar region would bring a similar effect, but it was not observed.

It appears that the lack of effects of epidural anesthesia on PWD may, to a large extent, be explained by the fact that according to current knowledge, epidural anesthesia does not cause complete sympathetic blockade. The fact that blockade of the sympathetic part of the ANS occurring during TEA is not complete is confirmed by Bourke et al., who compared the efficacy of TEA with the surgical sympathetic denervation of the heart in patients with treatment-resistant ventricular arrhythmias. A surgical procedure was more effective than epidural anesthesia, which may be associated with the presence of incomplete sympathetic blockade after TEA [18]. Additional evidence to support incomplete blockade of the sympathetic fibers occurring during epidural blockade is provided by Meissner et al., who - using an animal model - proved that the weakened conduction of sympathetic impulses observed after epidural anesthesia can be made more profound by systemic administration of propranolol, atropine and hexamethonium [19].

If we assume that only complete sympathetic blockade may lead to significant electrophysiological effects, the fact that epidural anesthesia only reduces sympathetic impulses without their complete elimination [20] can account for the lack of significant changes in the parameters of atrial electrophysiology in our study. This can be further supported by the fact that significant effects of pharmacological blockade on sympathetic impulses were described by the majority of authors only after chronic use of $\beta$-blockers [21]. Similar reservations were expressed in a publication on the effects of epidural anesthesia in the thoracic or lumbar segment on cardiac repolarization. The authors observed the effects of epidural anesthesia in the thoracic segment on the corrected QT interval only in the cases in which it was corrected using Bazett's formula, whereas no changes were observed in the cases in which the Fridericia formula and the Framingham equation were used. The first method of correction depends highly on the heart rate, and therefore the observed changes in the QTc value were interpreted by the authors as the ones caused by TEAinduced reduction of the heart rate, rather than by complete sympathetic blockade [22]. Additional arguments in favor of limited effects of sympathetic denervation of the heart on the studied ECG parameters reflecting electrophysiology of the atria are provided by the study of Nussinovitch et al. involving patients with congenital denervation of the cardiovascular system. As a result of a comparison between patients with familial dysautonomia and a control group, no differences between them were observed with regard to the maximum, minimum and mean $P$ wave duration and the $P$ wave dispersion values. There were also no intergroup differences with regard to the frequency of incidents of supraventricular tachyarrhythmia [23].

Another factor that could potentially affect the obtained results is the systemic effects of bupivacaine, an LA with a significant affinity to ion channels in the myocardial cells [24]. There are no reports on the effects of this agent on the electrophysiology of the atria. Although in this study the bupivacaine concentrations in the blood serum of patients were not measured, it appears that they were low when a desired level of blockade was achieved. Taverne et al. [25] studied the bupivacaine levels in the blood in conscious patients after the administration of $20 \mathrm{~mL}$ of $0.5 \%$ solution into the epidural space, and - at time points similar to the ones in our study - they ranged from 0.4 to $0.5 \mu \mathrm{g} \mathrm{mL}$. These levels are a few times lower than the ones considered to affect the electrical myocardial function significantly. Moreover, at such levels bupivacaine is approx. 90\% bound to proteins [24]; therefore, the pool of the free drug responsible for its toxic effects is very low.

Due to the fact that in the study we conducted there were no effects of epidural anesthesia on the electrophysiological parameters of the cardiac atria associated with an increased risk of atrial fibrillation, one should address the question of whether there is a real relationship between epidural blockade and supraventricular cardiac arrhythmias. It appears that discovering a direct relationship between TEA and the prevention of supraventricular arrhythmias can be difficult, if not impossible, due to the complexity of 
its underlying factors. When searching for such a relationship, the effects of anesthesia and anesthetics on complex mechanisms responsible for the disturbances in the cardiac electrophysiology have to be identified. The present study results are an attempt to explain these effects, at least with respect to the electrical function of the cardiac atria.

The main limitation of the study is the exclusive enrollment of patients without cardiovascular risk factors. It cannot be ruled out that different study results might have been obtained in patients with positive cardiovascular risk factors, such as paroxysmal ventricular tachyarrhythmias. On the other hand, such patients are almost always subject to chronic pharmacotherapy affecting the parameters analyzed in this study.

\section{Conclusions}

In conclusion, regardless of its location, epidural anesthesia and the sympathetic blockade associated with this procedure do not significantly affect the electrical functions of the cardiac atria reflected in superficial ECG, including the electrocardiographic parameters that are considered to be markers of increased risk of perioperative atrial fibrillation, such as $\mathrm{P}$ wave dispersion and its maximum duration.

\section{Disclosure}

The authors report no conflicts of interest.

\section{References}

1. Kamibayashi T, Hayashi Y, Mammoto T, Yamatodani A, Taenaka N, Yoshiya I. Thoracic epidural anesthesia attenuates halothane-induced myocardial sensitization to dysrhythmogenic effect of epinephrine in dogs. Anesthesiology 1995; 82: 129-134.

2. Siebert J, Anisimowicz L, Lango R, Rogowski J, Pawlaczyk R, Brzezinski M. Atrial fibrillation after coronary artery bypass grafting: does the type of procedure influence the early postoperative incidence? Eur J Cardiothorac Surg 2001; 19: 455-459.

3. Svircevic V, van Dijk D, Nierich AP, Passier MP, Kalkman CJ. Meta-analysis of thoracic epidural anesthesia versus general anesthesia for cardiac surgery. Anesthesiology 2011; 114: 271-282.

4. Dilaveris PE, Gialafos EJ, Andrikopoulos GK. Clinical and electrocardiographic predictors of recurrent atrial fibrillation. Pacing Clin Electrophysiol 2000; 23: 352-358.

5. Cheema AN, Ahmed MW, Kadish AH, Goldberger JJ. Effects of autonomic stimulation and blockade on signal-averaged P-wave duration. J Am Coll Cardiol 1995; 26: 497-502.

6. Gunduz H, Binak E, Arinc H, Akdemir R, Ozhan H, Tamer A, Uyan C. The relationship between $\mathrm{P}$ wave dispersion and diastolic dysfunction. Tex Heart Inst J 2005; 32: 163-167.
7. Turgut O, Yilmaz MB, Yilmaz A, Yalta K. Acute coronary syndrome: shortterm effects of early intravenous metoprolol on maximum $P$ wave duration and P wave dispersion. Adv Ther 2007; 24: 14-22.

8. Erbay AR, Turhan H, Yasar AS, Bicer A, Senen K. Effects of long-term betablocker therapy on $\mathrm{P}$-wave duration and dispersion in patients with rheumatic mitral stenosis. Int J Cardiol 2005; 102: 33-37.

9. Budeus M, Hennersdorf M, Dierkes S, Preik M. Effects of right coronary artery PTCA on variables of P-wave signal averaged electrocardiogram. Ann Noninvasive Electrocardiol 2003; 8: 150-156.

10. Dogan SM, Yildirim N, Gursurer M, Aydin M, Kalaycioglu E, Cam F. P-wave duration and dispersion in patients with coronary slow flow and its relationship with thrombolysis in myocardial infarction frame count. J Electrocardiol 2008; 41: 55-59.

11. Turkmen M, Barutcu I, Esen AM, Karakaya O, Esen O, Basaran Y. Effect of slow coronary flow on P-wave duration and dispersion. Angiology 2007; 58: 408-412.

12. Chandy J, Nakai T, Lee RJ, Bellows WH, Dzankic S, Leung JM. Increases in P-Wave dispersion predict postoperative atrial fibrillation after coronary artery bypass graft surgery. Anesth Analg 2004; 98: 303-310.

13. Camsari A, Pekdemir H, Akkus MN, Yenihan S, Doven O, Cin VG. Long-term effects of beta blocker therapy on P-wave duration and dispersion in congestive heart failure patients: a new effect? J Electrocardiol 2003; 36: 111-116.

14. Uyarel H, Kasikcioglu H, Dayi SU, Okmen E, Cam N. Anxiety and P wave dispersion in a healthy young population. Cardiology 2005; 104: 162-168.

15. Altun A, Erdogan O, Tatli E, Ugur-Altun B, Durmus-Altun G, Ozbay G. Increased $\mathrm{P}$ wave dispersion: a new finding in patients with syndrome $\mathrm{X}$. Can J Cardiol 2002; 18: 1207-1210.

16. Taniguchi M, Kasaba T, Takasaki M. Epidural anaesthesia enhances sympathetic nerve activity in the unanesthetized segments in cats. Anesth Analg 1997; 84: 391-397.

17. Owczuk R, Sawicka W, Wujtewicz MA, Kawecka A, Lasek J, Wujtewicz M. Influence of spinal anesthesia on corrected QT interval. Reg Anesth Pain Med 2005; 30: 548-552.

18. Bourke T, Vaseghi M, Michowitz Y, Sankhla V, Shah M, Swapna N, Boyle NG, Mahajan A, Narasimhan C, Lokhandwala Y, Shivkumar K. Neuraxial modulation for refractory ventricular arrhythmias: value of thoracic epidural anesthesia and surgical left cardiac sympathetic denervation. Circulation 2010; 121: 2255-2262.

19. Meissner A, Eckardt L, Kirchhof P. Effects of thoracic epidural anesthesia with and without autonomic nervous system blockade on cardiac monophasic action potentials and effective refractoriness in awake dogs. Anesthesiology 2001; 95: 132-138.

20. Magnusdottir H, Kirno K, Ricksten SE, Elam M. High thoracic epidural anesthesia does not inhibit sympathetic nerve activity in the lower extremities. Anesthesiology 1999; 91: 1299-1304.

21. Chizzola PR, Gonçalves de Freitas HF, Marinho NVS. The effect of $\beta$-adrenergic receptor antagonism in cardiac sympathetic neuronal remodeling in patients with heart failure. Int J Cardiol 2006; 106: 29-34.

22. Owczuk R, Steffek M, Wujtewicz MA, Szymanowicz W, Twardowski P, Marjanski T, Wojciechowski J, Zienciuk A, Rzyman W, Wujtewicz M. Effects of thoracic epidural anaesthesia on cardiac repolarization. Clin Exp Pharmacol Physiol 2009; 36: 880-883.

23. Nussinovitch $U$, Katz $U$, Nussinovitch $M$, Nussinovitch N. P-Wave dispersion in familial dysautonomia. Isr Med Assoc J 2010; 12: 729-731.

24. Heavner JE. Cardiac toxicity of local anesthetics in the intact isolated heart model: a review. Reg Anesth Pain Med 2002; 27: 545-555.

25. Taverne RH, Ionescu TI, Dijk AV. Pharmacokinetic profile of epidurally injected bupivacaine in awake patients. Clin Drug Investig 1998; 15: 309-317. 